4-7-2015

\title{
The Relationship Between Firm Resources and Joint Ventures: Revisited
}

Vivien E. Jancenelle

Cleveland State University, v.jancenelle@vikes.csuohio.edu

Follow this and additional works at: https://engagedscholarship.csuohio.edu/bus_stupub

Part of the Finance and Financial Management Commons, Management Sciences and Quantitative Methods Commons, and the Strategic Management Policy Commons

How does access to this work benefit you? Let us know!

Publisher's Statement

This article is (C) Emerald Group Publishing and permission has been granted for this version to appear here: http://www.emeraldinsight.com/doi/abs/10.1108/AJB-07-2014-0045. Emerald does not grant permission for this article to be further copied/distributed or hosted elsewhere without the express permission from Emerald Group Publishing Limited.

\section{Original Published Citation}

Vivien E. Jancenelle, (2015) "The relationship between firm resources and joint ventures: revisited", American Journal of Business, Vol. 30 Iss: 1, pp. 8 - 21

This Article is brought to you for free and open access by the Monte Ahuja College of Business at EngagedScholarship@CSU. It has been accepted for inclusion in Business Student Publications by an authorized administrator of EngagedScholarship@CSU. For more information, please contact library.es@csuohio.edu. 


\title{
The relationship between firm resources and joint ventures: revisited
}

\author{
Vivien E. Jancenelle \\ Department of Management, Monte Ahuja College of Business, \\ Cleveland State University, Cleveland, Ohio, USA
}

\begin{abstract}
Purpose - This study is a replication of Wolff and Reed's (2000) work. The purpose of this paper is to examine how the combination of resources brought to joint ventures influence parent-firm performance. This study is also interested in whether or not the exposure of immobile resources through the semi-transparent membrane of the joint venture can have negative effects on parent-firm performance.

Design/methodology/approach - The sample consists of two-parent joint ventures formed by publicly traded US firms between 1997 and 2013. The event-study methodology is used to calculate each parent-firm's abnormal returns. This work also uses content analysis to analyze parent-firms' annual reports (10-K).

Findings - While Wolff and Reed's results on resource allocation within joint ventures were not statistically significant, this replication study provided strong support to the resource allocation hypothesis. It was found that intangible resource heterogeneity within a joint venture creates higher performance gains for parent-firms than tangible resource heterogeneity. This work also successfully replicated Wolff and Reed's findings on the negative impact of immobile resources exposure on parent-firm performance. Wolff and Reed's results on resource complementarity were, however, not successfully replicated.

Originality/value - This replication study goes beyond simply showing that engaging in a joint venture strategy creates value for parent-firms. Through the use of a new content analysis method, this study was able to provide strong support for Wolff and Reed's theory on the performance gains provided by resource heterogeneity in a joint venture setting, and to confirm the results on potential adverse performance effects of immobile resources exposure.
\end{abstract}

Keywords Strategic management, Joint ventures, Event-study, Firm resources

Paper type Research paper

\section{Introduction}

This replication study focusses on how the relationship between joint ventures and firm resources can improve parent-firm performance. Firms adopt joint venture strategies for diverse reasons. Berg and Friedman (1977) investigated the motivations for creating a joint venture and found that major goals included the acquisition of new skills or know-how, the acquisition of distribution or production facilities, the research and development of a new product or the acquisition of capital. The motivations to joint venture all seem related to increasing parent-firm performance in some way. Koh and Venkatraman (1991) identified four major parent-firm benefits that may lead to higher performance as a result of entering into a joint venture. These potential benefits include reducing costs and sharing risk, accessing economies of scale, shaping the scope of competition and accessing complementary assets. Such benefits of joint ventures

The author would like to thank Dr Susan F. Storrud-Barnes and Dr Richard Reed for the helpful comments and suggestions throughout the development of this replication study.

This is a post-print. Published version: Jancenelle, V. E. (2015). The relationship between firm resources and joint ventures: revisited. American Journal of Business, 30(1), 8-21. http://dx.doi.org/10.1108/AJB-07-2014-0045 
have been confirmed by many empirical studies which showed that parent-firms achieve on average higher performance results after entering a joint venture (e.g. McConnell and Nantell, 1985; Koh and Venkatraman, 1991; Wolff and Reed, 2000).

As just discussed, much research has shown that firms can improve their performance with joint ventures, but there is also a body research highlighting the drawbacks of forming joint ventures. For example, Koh and Venkatraman's (1991) highly cited work points out that joint ventures induce high potential costs, such as coordination costs, adverse bargaining position costs for minority owners of the joint venture and the potential erosion of a competitive position as a result of the loss of proprietary knowledge or expertise. Some studies suggest that joint ventures can have negative performance effects on parent-firms, like in Chung et al.'s (1993) study of international joint ventures.

McConnell and Nantell's (1985) definition of a joint venture emphasizes on the key role of parent-firm resource allocation: "A joint venture involves the joining together of a subset of the resources of two or more parent companies to accomplish some objective under the combined management of the two parent companies." Such a definition agrees with Wolff and Reed's (2000, p. 269) view that the gains from a joint venture strategy depend upon the resources that firms bring.

This replication study attempts to address the question of resource allocation in joint ventures, and how it influences parent-firm performance, by replicating the work of Wolff and Reed (2000). I will be using a more recent sample drawn from the same population, and a partially different method. On one hand, consistent with much joint venture research (e.g. McConnell and Nantell, 1985; Koh and Venkatraman, 1991; Wolff and Reed, 2000), this study uses the event-study methodology (Fama et al., 1969) to establish performance measurements. On the other hand, this study's independent variables will be established differently, through the use of an advanced computational linguistic software with extensive preset dictionaries.

In the remainder of this paper, I first review the literature on how firm resources can influence performance and competitive advantage. I then provide a brief overview of Wolff and Reed's (2000) work, including their hypotheses and findings. The replication study's similarities and differences with the work of Wolff and Reed (2000) are then introduced. Next, I present the methods and results of this work. This paper is concluded by a discussion of my findings and their implications.

\section{Theoretical background}

Most researchers agree that firm resources can be defined as either tangible or intangible. A review of the resource-based view literature shows that many influential works attempting to identify different types of firm resources fit the tangible-intangible classification. For example, Barney (1991) classified resources as either physical (tangible), or human/organizational (intangible). Hofer and Schendel (1978) identified five main resources which can be grouped as tangible (financial and physical) and intangible (organizational, human and technological). Chatterjee and Wernerfelt's (1991) have also categorized resources as either tangible (physical, financial) or intangible (i.e. marketing skills, innovation, research and development skills).

Much research seems to show that intangible resources are one of the key sources of competitive advantage. For example, Barney (1991, p. 107) mentioned that "valuable and rare organizational resources can only be sources of sustained competitive advantage if firms that do not possess these resources cannot obtain them." Causal ambiguity is one

This is a post-print. Published version: Jancenelle, V. E. (2015). The relationship between firm resources and joint ventures: revisited. American Journal of Business, 30(1), 8-21. http://dx.doi.org/10.1108/AJB-07-2014-0045 
of the key reasons why some intangible firm resources may only be imperfectly imitable (Barney, 1986). Scholars like Reed and Defillippi (1990) argued that the tacitness, complexity and specificity of a firm's skills and resources create a competitive advantage that is difficult to overcome by imitation.

Resource heterogeneity between firms at the industry level plays a key role for establishing competitive advantage. A firm that possesses valuable resources (those that improve the efficiency and effectiveness of the firm) and rare resources (different from what the competition has) will only reach a short term competitive advantage. A firm's resources must also be imperfectly imitable in order to achieve sustainable competitive advantage (Barney, 1991). These imperfectly imitable resources are usually embedded in the intangible resources of the firm, and are invisible (Itami and Roehl, 1987). They are also seen as one of the main drivers of competitive advantage, because they cannot be easily purchased on open markets (Barney, 1986), and are often hard to imitate because of protective causal ambiguity (Reed and Defillippi, 1990).

This work posits that the resource-based view of competitive advantage at the industry level should also apply at the joint venture level. Factors such as resource heterogeneity within joint ventures should influence parent-firm performance. Intangible resource heterogeneity should also have a stronger influence on parent-firm performance than tangible resource heterogeneity, as imperfectly imitable resources, a major driver of sustainable competitive advantage (Barney, 1991), is embedded in the intangible resources of the firm (Itami and Roehl, 1987). This work also posits that the exposure of intangible resources through a joint venture could unintentionally lead to exposing imperfectly imitable resources that were previously protected by the distance between firms. In such a situation, the causal ambiguity surrounding the operation of the firm may be diminished (Reed and Defillippi, 1990).

\section{Review of Wolff and Reed's (2000) study}

Theory and hypotheses

Wolff and Reed's (2000) study elected to use Hofer and Schendel's (1978) classification of resources as tangible and intangible. A major difference between tangible and intangible resources lies in the fact intangible resources (such as human or organizational capital) cannot be easily acquired in factor markets, and are therefore considered to be one of the principal drivers of competitive advantage (Barney, 1991). Wolff and Reed's first hypothesis draws on the fact that firms who gain access to intangible resources through a joint venture will achieve a higher performance than firms who gain access to tangible resources, as intangible resources are known to include imperfectly imitable resources (Itami and Roehl, 1987). These specific resources are known to be hard to imitate or obtain through factor markets, and are considered to be one of the main sources of sustainable competitive advantage (Barney, 1991). The first hypothesis posits that joint ventures combining tangible resources (easily obtainable through factor markets) will lead to lower parent-firm performance than joint ventures combining intangible resources (difficult to obtain in factor markets). In other words, intangible resource heterogeneity (when one parent-firm brings more intangible resources to the joint venture than the other) will lead to higher overall parent-firm performance than tangible resource heterogeneity (when one parent-firm brings more tangible resources to the joint venture than the other). These arguments lead to the following hypothesis:

H1. There are greater improvements to parent-firm performance from joint ventures with intangible resource heterogeneity than joint ventures with tangible resource heterogeneity.

This is a post-print. Published version: Jancenelle, V. E. (2015). The relationship between

firm resources and joint ventures: revisited. American Journal of Business, 30(1), 8-21. http://dx.doi.org/10.1108/AJB-07-2014-0045 
Wolff and Reed's (2000) second hypothesis is concerned with studying the potential performance gains created by resource complementarity between the parent-firms of a joint venture. Resource complementarity between parent-firms entering a joint venture should lead to performance gains because of the various benefits of complementarity, such as reduced financial risks (Kogut, 1991) or economies of scope (Harrigan, 1988). According to Wolff and Reed's (2000) study, resource complementarity between firms in a joint venture provide valuable benefits to parent-firms such as minimized transactions costs, spare capacity in resources and diverse benefits from inter-firm relationships. Joint venture theory suggests that joint ventures can be used to improve parent-firm performance through resource complementarity and the capitalization on each JV-parent's strengths (McWilliams and Gray, 1995). These arguments lead to the following hypothesis:

H2. There is a positive relationship between resource complementarity in a joint venture and parent-firm performance.

So far, both hypotheses from Wolff and Reed's (2000) study have focussed on the effects of combining parent-firm's resources at the joint venture level. $H 3$ is interested in studying each parent-firm individually, in order to study the potential drawbacks caused by the exposure of immobile resources through the creation of a joint venture. According to Reed and Defillippi (1990), intangible resource interactions is a key factor in sustaining a firm's competitive advantage, and therefore the exposure of intangible resources through the joint venture may lead to the unintentional exposure of valuable resources (Hamel, 1991):

H3. There is a negative relationship between the exposure of intangible-resource interactions through a joint venture and parent-firm performance.

Sample and methods

Wolff and Reed's (2000) study of firm resources and joint ventures focussed on 74 joint venture announcements from 1970 to 1990. Their sample comprised 74 JV-level observations and 148 firm-level observations. The research design used by Wolff and Reed ensured that all two-parent joint ventures in the sample were included in the analysis, without the removal of any potential outlier. Their work used the event-study methodology to measure firm performance (used as a dependent variable for all three hypotheses), and content analysis to analyze the annual reports of each parent-firm for the announcement year. Wolff and Reed's (2000) study uses six dictionaries of keywords and root words, covering financial (22 words), physical ( 25 words), human (25 words), organizational (53 words) and technological (nine words) resources. These six dictionaries were then used to calculate independent variables relating to tangible and intangible resource heterogeneity (H1), complementarity (H2) and resource mobility $(H 3)$.

\section{Results}

The first hypothesis of Wolff and Reed's (2000) study was rejected due to the insufficient significance level of the results. Findings suggested that tangible resource heterogeneity had a greater effect on parent-firm performance than intangible resource heterogeneity, but their results did not reach the 95 percent confidence level. Wolff and Reed's (2000) second hypothesis was confirmed at the 99 percent confidence level. The results showed that complementarity in tangible and intangible resources lead to higher performance for parent-firms. The third hypothesis tested by Wolff and

This is a post-print. Published version: Jancenelle, V. E. (2015). The relationship between firm resources and joint ventures: revisited. American Journal of Business, 30(1), 8-21. http://dx.doi.org/10.1108/AJB-07-2014-0045 
Reed (2000) was also confirmed at the 99 percent confidence level, confirming that the exposure of intangible-resource interactions impacts parent-firm performance negatively. Finally, the results of firm-level data analysis used for testing the third hypothesis were consistent with the work of other researchers. For example, the results confirmed that industry has a significant impact on joint venture performance, consistent with the work of Harrigan (1988). The results also confirmed that on average, the creation of a joint venture creates a positive return for parent-firms, consistent with the works of McConnell and Nantell (1985) and Koh and Venkatraman (1991).

\section{Discussion}

The main findings of Wolff and Reed's (2000) work were that complementarity between tangible and intangible resources brought to a joint venture yields a performance benefit for parent-firms (H2), while the exposure of immobile resources, without an access to equivalent immobile resources, yields a performance penalty $(H 3)$. Wolff and Reed believe that results may have been too conservative, partially because of the research design. The authors used Hofer and Schendel's (1978) framework for the classification of resources into tangible and intangible resources, which may have been an inadequate framework to use for this study as there is lack of consensus in the literature regarding what constitutes tangible resources and intangible resources (Wolff and Reed, 2000, p. 279).

\section{About this replication study}

This replication study seeks to answer the same research questions as Wolff and Reed's (2000) work, but uses a more recent sample (from 1997 to 2013), chosen from the same population (US joint ventures formed by two US publicly traded parent-firms). The methodology used to study the research questions reviewed above has also been partially changed. I first use the event-study methodology (Fama et al., 1969) to establish parent-firm performance, with the same two-day event window and 200-day return series as Wolff and Reed (2000). This performance calculation method is consistent with much work done on joint ventures (e.g. Koh and Venkatraman, 1991; McConnell and Nantell, 1985). I will, however, use a different content analysis software for the calculation of my independent variables relating to tangible and intangible resource heterogeneity $(H 1)$, complementarity $(H 2)$ and resource mobility $(H 3)$.

While Wolff and Reed (2000) established their tangibility and intangibility resource measures based on the classification framework of Hofer and Schendel (1978), which divided tangibility into two categories (financial and physical), and intangibility into three categories (human, organizational and technological), I established my tangibility and intangibility measurements with an advanced computational linguistic software based on seminal semantic studies. Therefore, my tangibility and intangibility measures both included substantially more search words than Wolff and Reed's (2000) study, all extracted from more keyword dictionaries (cf. the methods section of this paper). I decided to use this new content analysis methodology, as Wolff and Reed stated that Hofer and Schendel's (1978) classification of resources may have been inappropriate for their study (Wolff and Reed, 2000, p. 279). The software used (Diction) and how I established each independent variable is further explained in the method section of this paper.

$H 1$ and $H 2$ remain unchanged for this replication study (same formulation). The first hypothesis will study the impact of tangible and intangible heterogeneity levels on

This is a post-print. Published version: Jancenelle, V. E. (2015). The relationship between

firm resources and joint ventures: revisited. American Journal of Business, 30(1), 8-21. http://dx.doi.org/10.1108/AJB-07-2014-0045 
combined parent-firm performance. The second hypothesis will study the impact of resource complementarity (when one parent-firm brings more tangible resources to the joint venture, while the other parent-firm brings more intangible resources to the joint venture) on combined parent-firm performance. The $H 3$ needs to be rewritten in this way: "There is a negative relationship between the exposure of intangible resources through a joint venture and parent-firm performance." I reformulated this hypothesis because this work will only be studying the exposure of intangible-resources through the joint venture, as the calculation of intangible-resource interactions was linked to the use of Hofer and Schendel's (1978) sub-classification of intangible resources. This classification of resources has not been reused in this replication study, as Wolff and Reed (2000, p. 279) mentioned it may have been an inappropriate choice.

\section{Method \\ Sample}

The sample used for this study consisted of joint ventures formed anytime from 1997 to 2013, inclusive. Consistent with previous work done on joint ventures (Wolff and Reed, 2000; Koh and Venkatraman, 1991), I had to restrict the sample to two-parent joint ventures with a 50/50 ownership split, in order to better assess the contributions and gains of each partner entering the joint venture. Each parent-firm also had to be based in the USA, and publicly traded on either the NYSE or NASDAQ in order for me to analyze the SEC annual reports $(10-\mathrm{K})$ of each firm creating a joint venture. The joint ventures were identified through announcements made in the Wall Street Journal. I only selected the joint ventures that strictly fit the criteria explained above, using the date of the first appearance of each new joint venture in the Wall Street Journal as the announcement day to be used for the calculation of abnormal returns. My final sample consisted of $40 \mathrm{JV}$-level observations (needed for $H 1$ and $H 2$ ) and 80 firm-level observations (needed for $H 3$ ).

\section{Performance}

Consistent with previous studies on joint ventures (Wolff and Reed, 2000; Koh and Venkatraman, 1991; McConnell and Nantell, 1985), I used the event-study methodology (Fama et al., 1969) in order to calculate each firm's performance on the day of the JV-announcement. There is a large body of work that uses event-studies to analyze the impact of corporate press (e.g. earnings press release, JV announcements) on stock price and overall performance (e.g. Henry, 2008; Wolff and Reed, 2000; McConnell and Nantell, 1985). For this study, I elected to use a two-day event window corresponding to the day of the new joint venture announcement, and the day preceding the announcement $(t-1, t-0)$. Stock returns and market data for this study was obtained from the Center for Research in Security Prices, for firms publicly traded on the NYSE and NASDAQ. Each abnormal return for each firm's two-day event window was calculated using a 200-day return series beginning with day $t-270$ and ending with day $t-71$. The dependent variable used for testing $H 1$ and $H 2$ (JV-level observations) was obtained by summing the two-day cumulative abnormal returns of each set of parent-firms. For testing $H 3$ (firm-level observations), I used each parent-firm's two-day cumulative abnormal return separately as a dependent variable.

\section{Content analysis using diction}

Each parent-firm's annual report has been analyzed with a computer-aided content analysis software called Diction. This software was initially developed to analyze

This is a post-print. Published version: Jancenelle, V. E. (2015). The relationship between firm resources and joint ventures: revisited. American Journal of Business, 30(1), 8-21. http://dx.doi.org/10.1108/AJB-07-2014-0045 
political speech and rhetoric (Hart, 2000), but has since been further developed to be used for a variety of research interests, such as the analysis earnings press releases (Henry, 2008) or the analysis of corporate annual reports (Yuthas et al., 2002). This program has also been shown to possess strong empirical validity for content analysis research in strategic management (Short and Palmer, 2008). Diction uses a series of 31 predefined variables based on dictionaries, representing 10,000 unique search words that were developed from the study of US texts, including business texts such as mission statements, CEO speeches, and annual reports (Hart, 2000). Diction's predefined dictionary variables contain no duplicate words and are based on linguistic theory and seminal semantic studies (Easton, 1940; Osgood et al., 1957). Each text analyzed with Diction is given a word count standardized to 500 words for any of the predefined dictionary selected by the researcher. Each dictionary variable score includes a minor statistical accommodation for homographs inspired by the early work of Easton (1940) regarding word frequency. The Diction software also features four calculated variables and five master variables. Calculated variables do not rely on word counts, but are scores based on specific text patterns such as the repetition of words, the ratio of adjectives to verbs, the type-token ratio (Johnson, 1946) and the average number of characters per word. The master variables represent five broad semantic features (certainty, activity, optimism, realism and commonality) that are based on a combination of both the predefined dictionary variables and the calculated variables. For this content analysis, I elected to use the latest version of this software, Diction 7.0, to analyze the sample's annual reports with a set of nine predefined dictionary variables (see Table I).

Tangible and intangible resource heterogeneity. Our first hypothesis requires measuring the levels of tangible and intangible resources displayed by each parentfirm. In order to do so through content analysis with Diction, I had to select the predefined dictionary variables most representative of both tangible and intangible resources. Wolff and Reed (2000) represented tangible resources with financial and physical words, and intangible resources with human, organizational and technological words. In a similar manner, I chose the predefined dictionary variables offered by Diction that were most representative of tangibility and intangibility. Table I represents the combinations of predefined dictionary variables used to establish tangibility and intangibility measures.

Each combination of predefined dictionary variables for tangible resources and intangible resources allowed me to determine the resource levels of each firm. In order to calculate tangible and intangible resource heterogeneity, I subtracted the scores obtained by the two parents of each joint venture for both tangibility and intangibility measures. Heterogeneity levels for both tangible and intangible resources were obtained by computing the difference in scores between the two parent-firms (see Table II). The difference in scores (absolute value) for intangible resource heterogeneity and tangible resource heterogeneity were used as independent variables for this study's $40 \mathrm{JV}$-level observations.

Complementarity. An independent variable representing complementary is required for testing the second hypothesis of this study. I decided to follow Wolff and Reed's (2000) view that complementarity is likely to exist when one parent-firm brings more tangible resources to the joint venture while the other parent-firm brings more intangible resources. Conversely, complementarity is less likely to exist when one JV-parent brings both more tangible and more intangible resources than the other JV-parent. For this independent variable, I coded as 1 each JV-level observation where

This is a post-print. Published version: Jancenelle, V. E. (2015). The relationship between firm resources and joint ventures: revisited. American Journal of Business, 30(1), 8-21. http://dx.doi.org/10.1108/AJB-07-2014-0045 


\begin{tabular}{|c|c|c|}
\hline Measure & Diction variables & Brief description of the dictionary \\
\hline \multirow[t]{2}{*}{$\begin{array}{l}\text { Tangible } \\
\text { resources }\end{array}$} & $=$ Concreteness + & $\begin{array}{l}\text { Concreteness is a large dictionary focussing on tangibility and } \\
\text { materiality. Included are physical structures and goods } \\
\text { (e.g. building, factory, plants, equipment, stock) and financial } \\
\text { terms (e.g. stock, mortgages, wages) }\end{array}$ \\
\hline & Spatial terms & $\begin{array}{l}\text { A dictionary relating to physical locations (e.g. domains, vacant, } \\
\text { spacious, land) }\end{array}$ \\
\hline \multirow[t]{7}{*}{$\begin{array}{l}\text { Intangible } \\
\text { resources }\end{array}$} & $=$ Collectives + & $\begin{array}{l}\text { Words connoting plurality (e.g. words relating to social groupings, } \\
\text { task groups, organizational systems) }\end{array}$ \\
\hline & Human interest+ & Generic terms highlighting interests in people and their activities \\
\hline & Cooperation+ & $\begin{array}{l}\text { Terms designating behavioral interactions that result in a group } \\
\text { product (e.g. network, exchange, teamwork, contributions, words } \\
\text { relating to formal work relations) }\end{array}$ \\
\hline & Diversity+ & $\begin{array}{l}\text { Words describing individuals or groups differing from the norm } \\
\text { (e.g. non-conformist, exceptional, unique, far-flung) }\end{array}$ \\
\hline & Communication+ & $\begin{array}{l}\text { Terms referring to social interactions, both face-to-face and } \\
\text { mediated, as well as social actors (e.g. managers, worker, } \\
\text { employee) }\end{array}$ \\
\hline & Inspiration+ & $\begin{array}{l}\text { Traits and virtues deserving universal respect, such as moral } \\
\text { qualities (e.g. virtue, honesty, self-sacrifice) or personal qualities } \\
\text { (dedication, courage, wisdom) }\end{array}$ \\
\hline & Cognition & $\begin{array}{l}\text { Words referring to cerebral processes, including modes of } \\
\text { discovery (e.g. learn), mental challenges, words relating to } \\
\text { intuitions (e.g. perceive, speculate, interpret), to rational thinking } \\
\text { (estimate, strategize) and calculative thinking (diagnose, analyze) }\end{array}$ \\
\hline
\end{tabular}

Source: Hart (2000)

Table II.

Tangible and

Level of tangible resource

heterogeneity $=$

Level of intangible resource

heterogeneity $=$
Absolute value of (tangible resources of JV-parent 1 - tangible resources of JV-parent 2)

Absolute value of (intangible resources of JV-parent 1 - intangible resources of JV-parent 2)
Table I.

Combination and description of predefined dictionary

variables

the first parent brought more tangible resources to the joint venture than the second parent, while the second parent brought more intangible resources to the joint venture than the first parent. Out of the 40 two-parent joint ventures analyzed, 14 were identified as complementary.

Resource mobility. The third hypothesis is concerned with the study of parent-firms who exposed immobile resources through a joint venture. Wolff and Reed (2000) have operationalized immobility through their measures of intangible resources. Resource immobility refers to the inability to transfer resources from one firm to another (Barney, 1991), due to their absence from factor markets as well as their inimitability. Immobile resources are known to be intangible in nature (Itami and Roehl, 1987); the immobility measure was therefore operationalized by the comparison of Diction's variables relating to intangibility (collectives, human interest, cooperation, diversity, communication, inspiration and cognition) for each parent-firm. For each joint venture, I computed both parent-firm's overall intangibility levels. Then, for each dyad, the parent who exhibited

This is a post-print. Published version: Jancenelle, V. E. (2015). The relationship between firm resources and joint ventures: revisited. American Journal of Business, 30(1), 8-21. http://dx.doi.org/10.1108/AJB-07-2014-0045 
the lowest intangibility level was not considered to be exposing intangible resources (0), while the parent who exhibited the highest intangibility level was deemed to be exposing the difference with its joint venture partner.

\section{Control variables}

H1 and H2 are both JV-level analyses, requiring little need for control variables. Consistent with the Wolff and Reed's (2000) study, we know that in a JV-level cross-sectional study, control variable implementation is greatly influenced by the JV parent-firms that created each joint venture. Therefore, there is little need to include control variables for $H 1$ and $H 2$, which occur at the JV level, but control variables are needed at the JV parent level.

Consistent with previous joint venture literature, the testing of $H 3$ (occurring at the parent-firm level) needs to include control variables. First, I controlled for size as it is known negatively correlate with JV parent-firm performance (Koh and Venkatraman, 1991). I controlled for size by multiplying the number of common shares outstanding at the day of the JV-announcement, by the stock price at the day of the JV-announcement. Our second control is derived from the work of Harrigan (1988), who found that parentfirm similarity contributed to JV-longevity and positive abnormal returns. Parent-firm similarity was operationalized by comparing the two-digit SIC codes reported in the CRSP database. I then coded firms who had a horizontal relationship (similar industry) as 1 and other relationships as 0 . I found that 22 parent-level firms created 11 joint ventures in similar industries. I also controlled for various industry groups, using the single digit SIC codes provided by CRSP. This sample ranged across eight different industries. A final control variable relates to joint venture experience. Following Wolff and Reed's (2000) methodology, I counted all JV announcements in the Wall Street Journal for each firm, from 1997 until each parent-firm's JV-announcement date. This announcement count was used as a measure of joint venture experience (all types of JVs were accounted for).

\section{Statistical analysis}

I used hierarchical regression (consistent with Wolff and Reed, 2000) to test the impact of tangible and intangible resource heterogeneity on parent-firm abnormal returns. I used simultaneous regression analysis for $H 2$ and $H 3$, in order to reveal the strength of association of complementarity and immobility with other variables.

\section{Results}

As indicated earlier, this replication study's sample consisted of 80 firm-level observations from 40 joint ventures. All observations were used in our analysis. Our 80 firm-level observations represented a total of 63 publicly traded companies, as some large corporations participated in more than one joint venture at different points in time throughout this study.

Table III shows descriptive statistics and correlations for the JV-level analysis (H1 and H2). It should be noted that the two-day cumulative abnormal return used in the JV-level analysis corresponds to the sum of parent-firm abnormal returns. The twoday cumulative abnormal return for each joint venture was $0.01937(\mathrm{SD}=0.07222)$ or 1.937 percent when expressed as a percentage. Table IV shows descriptive statistics and correlations for the firm-level analysis (H3). As can be seen, the two-day

This is a post-print. Published version: Jancenelle, V. E. (2015). The relationship between firm resources and joint ventures: revisited. American Journal of Business, 30(1), 8-21. http://dx.doi.org/10.1108/AJB-07-2014-0045 
cumulative abnormal return for individual parent-firms was $0.00968(\mathrm{SD}=0.04521)$, or 0.968 percent when expressed as percentage. Our results clearly indicate that joint ventures create, on average, positive gains in market value for parent-firms.

Table $\mathrm{V}$ presents the results of hierarchical and simultaneous regressions performed to test $H 1$ and $H 2$. $H 1$ was tested with hierarchical regression, and is confirmed at the 99 percent confidence level. Tangible resource heterogeneity explains 10.31 percent of the variance in performance $(p<0.01)$ while intangible resource heterogeneity explains 17.96 percent of the variance in performance $(p<0.01)$. As predicted by $H 1$, intangible resource heterogeneity explains more performance improvements (17.96 percent of the variance) than tangible resource heterogeneity (10.31 percent of the variance).

Table $\mathrm{V}$ also shows the results for the simultaneous regression performed to test $\mathrm{H} 2$. As can be seen, $H 2$ must be rejected due to insufficient statistical significance for the complementarity variable $(p>0.10)$.

Results for $H 3$ are shown on Table VI. It should first be noted that the results for our control variables are consistent with Wolff and Reed's (2000) study. Control variables relating to size, relationship and joint venture experience did not seem to have any statistically significant amount of impact on parent-firm performance $(p>0.10)$ while industry indicator variables were all significant $(p<0.01) . H 3$ was confirmed at the 95 percent confidence level, indicating that the exposure of intangible resources through a joint venture has a negative impact on parent-firm performance.

\section{Discussion}

The results of this study are consistent with much joint venture research, which show that on average, the creation of a joint venture improves parent-firm performance. Consequently, our study confirms that the results obtained by McConnell and Nantell (1985), Koh and Venkatraman (1991) and Wolff and Reed (2000) are still true today, thus confirming the benefits of joint ventures for parent-firms.

This replication study provided strong support to $H 1$, which was originally rejected in Wolff and Reed's (2000) study. This constitutes the main and strongest finding of this study. Intangible resource heterogeneity explained more of our sample's positive performance (17.96 percent of variance) than tangible resource heterogeneity (10.31 percent of variance). Hence, our results suggest that parent-firms benefit more from intangible resource heterogeneity than tangible resource heterogeneity. This finding confirms Wolff and Reed's (2000) theory on resource heterogeneity in the joint venture setting and suggests that, resource heterogeneity's impact on parent-firm performance is significant.

This study did not find any statistically significant impact on parent-firm performance from complementarity between intangible resources and tangible resources brought to joint venture. Wolff and Reed's (2000) study found a positive relationship between

\begin{tabular}{|c|c|c|c|c|c|c|}
\hline Variables & Mean & $\mathrm{SD}$ & 1 & 2 & 3 & \\
\hline 1. Tangible heterogeneity & 12.93575 & 10.52417 & 1 & & & \\
\hline 2. Intangible heterogeneity & 25.84475 & 11.65598 & $0.33368^{*}$ & 1 & & Table III. \\
\hline 3. Complementarity & 0.35 & 0.48305 & 0.08715 & -0.19166 & 1 & $\begin{array}{l}\text { 1 able III. } \\
\text { Descriptive statistics }\end{array}$ \\
\hline 4. 2-day cumulative abnormal return & 0.01937 & 0.07222 & $0.32117^{*}$ & -0.29225 & 0.04917 & and correlations for \\
\hline \multicolumn{6}{|l|}{ Notes: $n=40 . *$ Significant at 0.05 level } & JV-level variables \\
\hline
\end{tabular}

This is a post-print. Published version: Jancenelle, V. E. (2015). The relationship between firm resources and joint ventures: revisited. American Journal of Business, 30(1), 8-21. http://dx.doi.org/10.1108/AJB-07-2014-0045 
Table IV.

Descriptive statistics and correlations for firm-level variables

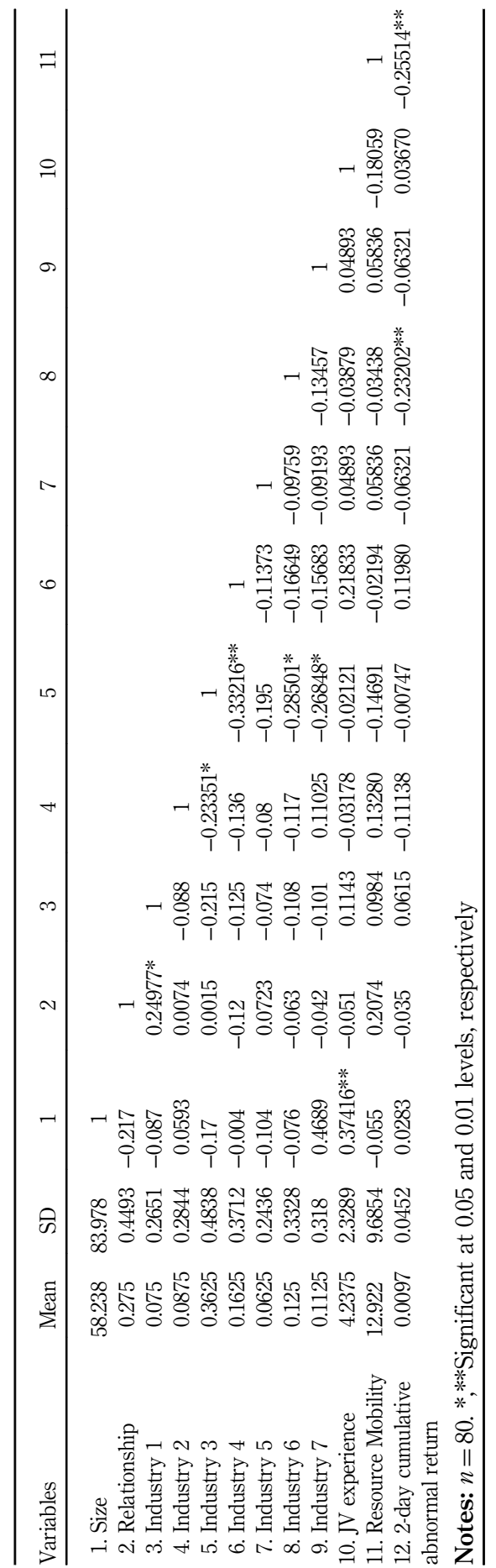

This is a post-print. Published version: Jancenelle, V. E. (2015). The relationship between firm resources and joint ventures: revisited. American Journal of Business, 30(1), 8-21. http://dx.doi.org/10.1108/AJB-07-2014-0045 
resource complementarity and parent-firm performance, however, they also stated in their discussion section that the "complementarity measure was so conservative, that the number of JVs identified as having resource complementarity was relatively small" (Wolff and reed, 2000, p. 278). In total, 35 percent of this replication study's JV-level observations were identified as complementarity (14 JVs out of 40), against only 8 percent for Wolff and Reed's (2000) study. This difference might be explained by the use of a different sample, but also by my use of a different method, seemingly less conservative. Our differences in results on complementarity could be explained by the fact that Wolff and Reed's (2000) sample did not include enough complementary joint ventures (six out of 74) to be generalizable to most joint ventures. The complementary joint ventures included in Wolff and Reed's (2000) sample could have also been exhibiting above average performance levels.

This work's last finding $(H 3)$ informed our understanding of the impact of resource mobility on parent-firm performance. Consistent with Wolff and Reed's (2000) findings, the exposure of intangible resources through a joint venture, without corresponding access to others' intangible resources, creates a loss in market value for parent-firms.

Overall, this replication study showed the strongest support $(\phi<0.01)$ for the impact of intangible and tangible resource heterogeneity on parent-firm performance,

\begin{tabular}{llllll}
\hline Variables & $R^{2}$ & Chg. $R^{2}$ & $F$ & $\beta$ & $t$ \\
\hline Hierarchical regression & & & & & \\
Tangible heterogeneity & 0.1031 & & $7.29^{* *}$ & & \\
Intangible heterogeneity & 0.2827 & 0.1796 & $9.26^{* *}$ & & \\
Simultaneous regression & & & & & \\
Intercept & & & 0.055929 & $2.03^{*}$ \\
Tangible heterogeneity & & & -0.00333 & $3.21^{* *}$ \\
Intangible heterogeneity & & & -0.01245 & $-0.07^{* *}$ \\
Complementarity & & & & & \\
\end{tabular}

Notes: Model $R^{2}=0.289$; adjusted $R^{2}=0.330$. Model $F$-test $=4.88^{* * *}$.***Significant at 0.05 and 0.01 levels, respectively

Table V.

Results of hierarchical and simultaneous regression for $H 1$ and $H 2$

\begin{tabular}{lcc}
\hline Variables & $\beta$ & $t$ \\
\hline Simultaneous regression & & \\
Intercept & 0.270845 & $8.17^{* *}$ \\
Size & $5.43 \mathrm{E}-11$ & 0.95 \\
Relationship & 0.00483 & 0.54 \\
Industry group 1 & -0.24728 & $-6.61^{* *}$ \\
Industry group 2 & -0.27185 & $-7.46^{* *}$ \\
Industry group 3 & -0.25942 & $-7.54^{* *}$ \\
Industry group 4 & -0.24703 & $-6.95^{* *}$ \\
Industry group 5 & -0.25261 & $-6.88^{* *}$ \\
Industry group 6 & -0.2853 & $-8.06^{* *}$ \\
Industry group 7 & -0.2711 & $-7.41^{* *}$ \\
JV experience & 0.000877 & 0.45 \\
Resource mobility & -0.00084 & $-2.05^{*}$
\end{tabular}

Notes: $n=80$. Model $R^{2}=0.539$; adjusted $R^{2}=0.465$. Model $F$-test $=7.25^{* *}$.****Significant at 0.05 and 0.01 levels, respectively

$$
\begin{gathered}
0.270845 \\
5.43 \mathrm{E}-11 \\
0.00483 \\
-0.24728 \\
-0.27185 \\
-0.25942 \\
-0.24703 \\
-0.25261 \\
-0.2853 \\
-0.2711 \\
0.000877 \\
-0.00084
\end{gathered}
$$

0.95

0.54

$-7.46^{* *}$

$-7.54 * *$

$-6.95^{* * *}$

$-6.88 * *$

$7.41^{* *}$

(1)
Regression of control variables and resource mobility

This is a post-print. Published version: Jancenelle, V. E. (2015). The relationship between firm resources and joint ventures: revisited. American Journal of Business, 30(1), 8-21. http://dx.doi.org/10.1108/AJB-07-2014-0045 
which constitutes a new finding. It was shown that intangible resource heterogeneity creates higher performance gains for parent-firms than tangible resource heterogeneity, giving credit to the validity of the resource heterogeneity construct in an intra-JV context. This study also showed significant support $(p<0.05)$ for the negative impact of intangible resource exposure on parent-firm performance, which is in accordance with Wolff and Reed's (2000) findings, and therefore confirms once again that the exposure of intangible resources through a joint venture diminishes protective causal ambiguity and increases the risk of revealing valuable immobile resources, which lead to lower parent-firm performance.

This replication study does not come without limitations. The sample selection criteria used in this study was restrictive in order to ensure an accurate resource assessment of the joint ventures. Each parent-firm needed to be publicly traded in order to perform an event-study, and listed on either the NYSE or NASDAQ in order to access each firm's SEC annual reports (10-K). Each parent-firm dyad also had to be equal partners in a joint venture to ensure comparability. Such a restrictive selection criteria made my sample much smaller than it could have been due to the high share of international joint ventures announcements present in the Wall Street Journal. I also identified numerous joint ventures in the technology sector, but many parent-firms did not happen to be publicly traded therefore could not be included in this sample. This restrictive criteria leads me to believe that the generalizability of this study may be limited. Another limitation of this study is inherent to the use of the event-study methodology (Fama et al., 1969). A two-day event window does not inform our understanding of actual long-term returns on investment of the joint venture, but is simply representative of the investors' expectations of what parent-firms will gain from creating a joint venture.

Future research should investigate whether the results of this replication study, as well as the results obtained by Wolff and Reed's (2000) study, hold true with international joint ventures. As mentioned earlier, my sample search yielded many more international joint ventures announcements than domestic joint ventures announcements. Extending the study of firm resource combinations and joint ventures at the international level would undoubtedly increase the generalizability of our knowledge of resource heterogeneity in joint ventures. Future research could also investigate whether the use of another performance variable (e.g. return on investment instead of two-day cumulative abnormal return) yields different results.

In conclusion, the present study aimed to re-test Wolff and Reed's (2000) three hypotheses on the role played by parent-firm resources in joint ventures, and their impact on performance. Using a partially new method, and a new data set, I was able to confirm two out of the three original hypotheses proposed by Wolff and Reed's (2000) study, going beyond simply showing that the joint venture strategy creates value for parent-firms.

\section{References}

Barney, J.B. (1986), "Strategic factor markets: expectations, luck and business strategy", Management Science, Vol. 32 No. 10, pp. 1231-1241.

Barney, J.B. (1991), "Firm resources and sustained competitive advantage", Journal of Management, Vol. 17 No. 1, pp. 99-120.

Berg, S.V. and Friedman, P. (1977), "Joint ventures, competition and technological complementarities: evidence from chemicals”, Southern Economic Journal, Vol. 43 No. 1, pp. 1330-1337.

This is a post-print. Published version: Jancenelle, V. E. (2015). The relationship between firm resources and joint ventures: revisited. American Journal of Business, 30(1), 8-21. http://dx.doi.org/10.1108/AJB-07-2014-0045 
Chatterjee, S. and Wernerfelt, B. (1991), "The link between resources and type of diversification: theory and evidence", Strategic Management Journal, Vol. 12 No. 1, pp. 33-48.

Chung, I.Y., Koford, K.J. and Lee, I. (1993), "Stock market views of corporate multinationalism: some evidence from announcements of international joint ventures", Quarterly Review of Economics and Finance, Vol. 33 No. 3, pp. 275-293.

Easton, H. (1940), Word Frequency Dictionary, Dover Publications, Mineola, NY.

Fama, E.F., Fisher, L., Jensen, M.C. and Roll, R. (1969), “The adjustment of stock prices to new information", International Economic Review, Vol. 1 No. 1, pp. 1-21.

Hamel, G. (1991), "Competition for competence and interpartner learning within international strategic alliances", Strategic Management Journal, Vol. 12, Summer, pp. 83-103.

Harrigan, K. (1988), "Joint ventures and competitive strategy", Strategic Management Journal, Vol. 9 No. 2, pp. 141-158.

Hart, R.P. (2000), DICTION 5.0: The Text-Analysis Program, Sage, Thousand Oaks, CA.

Henry, E. (2008), "Are investors influenced by how earnings press releases are written?", Journal of Business Communication, Vol. 45 No. 4, pp. 363-407.

Hofer, C.W. and Schendel, D. (1978), Strategy Formulation: Analytic Concepts, West, St. Paul, MN.

Itami, H. and Roehl, T. (1987), Mobilizing Invisible Assets, Harvard University Press, Cambridge, MA.

Johnson, W. (1946), People in Quandaries: The Semantics of Personal Adjustment, Harper, New York, NY.

Kogut, B. (1991), "Joint ventures and the option to expand and acquire", Management Science, Vol. 37 No. 1, pp. 19-33.

Koh, J. and Venkatraman, N. (1991), "Joint venture formations and stock market reactions: an assessment in the information technology sector", Academy of Management Journa Vol. 34 No. 4, pp. 869-892.

McConnell, J. and Nantell, T. (1985), "Corporate combinations and common stock returns: the case of joint ventures", Journal of Finance, Vol. 15 No. 2, pp. 519-536.

McWilliams, A. and Gray, S.R. (1995), "Understanding quasi-integration”, Journal of Business Strategies, Vol. 12 No. 1, pp. 69-85.

Osgood, C.E., Suci, G.J. and Tannenbaum, P. (1957), The Measurement of Meaning, University of Illinois Press, Urbana-Champaign, IL.

Reed, R. and DeFillippi, R.J. (1990), "Causal ambiguity, barriers to imitation, and sustainable competitive advantage", Academy of Management Review, Vol. 15 No. 1, pp. 88-102.

Short, J.C. and Palmer, T.B. (2008), "The application of DICTION to content analysis research in strategic management”, Organizational Research Methods, Vol. 11 No. 4, pp. 727-752.

Wolff, J.A. and Reed, R. (2000), "Firm resources and joint ventures: what determines zero-sum versus positive-sum outcomes?”, Managerial and Decision Economics, Vol. 21 No. 7, pp. 269-284.

Yuthas, K., Rogers, R. and Dillard, J.F. (2002), "Communicative action and corporate annual reports”, Journal of Business Ethics, Vol. 4 No. 1, pp. 141-157. 